\title{
OPTIMALISASI PUSAT PELAYANAN TERPADU PEMBERDAYAAN PEREMPUAN DAN ANAK DALAM MENANGANI KASUS KEKERASAN DALAM RUMAH TANGGA ${ }^{1}$
}

\author{
Ratna Herawati, Sekar Anggun Gading P*, Ayu Savitri Nurcahyani \\ Fakultas Hukum Universitas Diponegoro \\ J1. Prof. Soedarto, S.H, Tembalang, Semarang \\ sekar.anggun.gp@gmail.com
}

\begin{abstract}
Domestic violence is the case which growing every year in Indonesia. Most of the victims are women. To handle domestic violence cases, the government issued policies. Of the message from the various policies, formed Integrated Service Center as an institution that serves as well as accompanying battered women in each district or city. One of Integrated Service Centert as our object of this research is P2TP2A Semanah in district of Magelang. This research used empirical methods with data through interview and observation. Based on results, that the services provided by P2TP2A Semanah is enough optimal in handling their case in Magelang, but they have not safe house/shelter for the victims who need protection from threat of the perpetrator.
\end{abstract}

Keywords: Domestic Violence; Women; Integrated Service Center.

\begin{abstract}
Abstrak
Kekerasan dalam rumah tangga (KDRT) merupakan kasus yang jumlahnya terus bertambah setiap tahunnya di Indonesia. Sebagian besar korban KDRT adalah perempuan. Untuk menangani kasus KDRT, pemerintah mengeluarkan berbagai kebijakan. Dari amanat berbagai kebijakan tersebut, dibentuklah Pusat Pelayanan Terpadu Pemberdayaan Perempuan dan Anak (P2TP2A) sebagai lembaga yang melayani serta mendampingi perempuan korban kekerasan di setiap pemerintah daerah. Salah satu P2TP2A yang menjadi obyek penelitian ini adalah P2TP2A Semanah yang berada di Kabupaten Magelang. Adapun metode pendekatan yang digunakan adalah yuridis empiris dengan data melalui wawancara dan observasi. Berdasarkan hasil penelitian, bahwa pelayanan yang diberikan oleh P2TP2A Semanah sudah cukup optimal dalam menangani kasus KDRT, namun belum memiliki fasilitas rumah aman untuk para korban yang membutuhkan perlindungan dari ancaman pelaku.
\end{abstract}

Kata Kunci: KDRT; Perempuan; Pusat Pelayanan Terpadu.

\footnotetext{
${ }^{1}$ Penelitian ini adalah bagian dari Penelitian DIKTI dengan judul "Kajian Akademis Perlindungan Hukum dalam Mengurangi Angka Kekerasan terhadap Perempuan sebagai Upaya Peningkatan Kesehatan Mental di Provinsi Jawa Tengah", yang bersumber pada pendanaan dari Direktorat Riset dan Pengabdian Masyarakat DIKTI tahun 2020.
} 


\section{A. Pendahuluan}

Kasus kekerasan terhadap perempuan merupakan salah satu permasalahan yang tidak pernah surut. Kekerasan terhadap perempuan menurut CEDAW (Deklarasi PBB Tahun 1993, dan Convention on the Elimination of All Forms of Discrimination Against Women, 1999) merupakan setiap tindakan yang memiliki akibat kesengsaraan maupun penderitaan kepada perempuan secara fisik, seksual atau psikologis, termasuk ancaman tindakan tertentu, pemaksaan atau perampasan kemerdekaan secara sewenang-wenang baik yang terjadi di depan umum maupun dalam lingkungan kehidupan pribadi. Kekerasan terhadap perempuan tersebut dapat ditemukan hampir di seluruh penjuru dunia baik di negara berkembang maupun negara maju. Bahkan, Sustainable Development Goals (SDG's) atau yang dikenal dengan tujuan pengembangan dunia memiliki salah satu tujuan yaitu untuk mengurangi kekerasan terhadap perempuan serta kesetaraan gender yang harus dicapai pada tahun 2030. Kasus kekerasan perempuan yang tinggi tersebut didukung pula oleh data yang diterbitkan oleh WHO pada tahun 2018 yang menunjukkan bahwa sekitar 1 dari 3 (35\%) perempuan di seluruh dunia telah mengalami kekerasan pasangan intim baik fisik maupun seksual atau kekerasan non-seksual lainnya (Fazraningtyas, Dini Rahmayani, Indana Fitriani Rahmah, 2020).

Indonesia sebagai negara berkembang memiliki jumlah kasus kekerasan terhadap perempuan yang semakin meningkat per tahunnya dengan berbagai faktor penyebabnya, sehingga Indonesia telah memiliki kebijakan-kebijakan yang mengatur dan melindungi mengenai kekerasan terhadap perempuan. Kekerasan terhadap perempuan merupakan salah satu bentuk pelanggaran terhadap Hak Asasi Manusia (HAM), dimana di dalam konstitusi Negara Republik Indonesia sendiri diatur ketentuan mengenai Hak Asasi Manusia yang tertuang dalam Pasal 28 A sampai dengan Pasal 28 J UUD NRI Tahun 1945. Setiap warga negara berhak untuk mendapatkan rasa aman dan bebas dari segala bentuk kekerasan. Hal tersebut sebagai upaya Indonesia pula untuk melindungi segenap bangsa Indonesia dari berbagai kekerasan khususnya bagi para perempuan dan anak yang dianggap sebagai makhluk yang lemah sehingga rentan untuk terkena pelanggaran HAM.

Kasus kekerasan yang terjadi kepada perempuan tersebut sebagian besar didominasi oleh jenis Kekerasan Dalam Rumah Tangga (KDRT). KDRT yang merupakan kasus kekerasan yang terjadi di dalam rumah tangga yang sebagian besar korban KDRT tersebut adalah perempuan. Berdasarkan Catatan Tahunan (CATAHU) Komisi Nasional Anti Kekerasan terhadap Perempuan (Komnas Perempuan) bahwa pada 6 Maret 2019, jumlah kekerasan terhadap perempuan paling tinggi yaitu KDRT atau ranah personal yang mencapai angka $71 \%$ atau 9.637 kasus, dimana yang paling menonjol adalah kekerasan fisik mencapai 41\% atau 3.927 kasus. Data lain yang menunjukkan mengenai angka kekerasan terhadap perempuan yaitu Sistem Informasi Online Perlindungan Perempuan dan Anak (Simfoni) dari Kementerian Pemberdayaan Perempuan dan Anak (KEMENPPPA) per tahun 2020 terdapat total kasus kekerasan dengan korban perempuan sebanyak 10.428 yang tersebar di seluruh wilayah Indonesia. Kekerasan terhadap perempuan tersebut sebagian besar memang didominasi oleh kekerasan yang dialami di rumah tangga (KDRT) dengan presentase sebesar 56,8\% yang dialami oleh ibu rumah tangga dengan rentan usia paling banyak sekitar 25 tahun hingga 44 tahun dengan presentase $30,6 \%$.

Angka kekerasan yang begitu besar tersebut menunjukkan bahwa Indonesia masih memerlukan upaya keras untuk menangani kasus KDRT. Upaya untuk mengurangi jumlah KDRT tersebut tidak cukup dari pihak pemerintah saja yang melakukan, tetapi juga membutuhkan peran masyarakat. KDRT tersebut semakin meningkat dikarenakan kasus tersebut tidak terlepas dari nilai-nilai serta budaya yang 
sudah melekat di masyarakat seperti masih adanya budaya patriarki yang melekat di dalam masyarakat dimana budaya patriarki tersebut membuat adanya pelemahan terhadap derajat perempuan dan menguatkan derajat laki-laki (Farid, 2019). Di dalam budaya patriarki ini laki-laki yang memiliki dominasi lebih kuat dibanding perempuan sehingga mengakibatkan perempuan menjadi kaum marginal yang mudah untuk dikuasai, dieksploitasi serta diperbudak oleh kaum laki-laki (Mutmainah, Anisa, Santoso Tri Raharjo, Sahadi Humaedi, 2019). Budaya patriarki tersebut merupakan sebuah budaya dari masa lalu yang menganggap bahwa seorang perempuan hanya mengurus urusan rumah tangga saja dan belum ditemukan adanya kesetaraan gender. Hal tersebut menempatkan perempuan sebagai subordinat laki-laki. Selain itu, di pihak perempuan pun menganggap bahwa laki-laki atau suaminya tersebut merupakan seseorang yang harus dipatuhi serta seseorang yang tidak untuk dilawan. Dengan demikian ekstensi dan legitimasi praktik patriarki dalam domain pribadi untuk aspek kehidupan publik bergantung pada kehidupan, hak dan kebebasan perempuan. (Imam \& Bano, 2015)

Pemerintah dalam menangani kasus KDRT berdasarkan amanat UU Nomor 35 Tahun 2014 tentang Perubahan Atas UU Nomor 23 Tahun 2002 tentang Perlindungan Anak, UU Nomor 23 Tahun 2004 tentang Penghapusan Kekerasan Dalam Rumah Tangga, UU Nomor 13 Tahun 2006 tentang Perlindungan Saksi Korban dan UU Nomor 21 Tahun 2007 tentang Pemberantasan Tindak Pidana Perdagangan Orang dan Peraturan Menteri Negara Pemberdayaan Perempuan dan Perlindungan Anak Nomor 01 Tahun 2010 tentang Standar Pelayanan Minimal (SPM) Bidang Layanan Terpadu bagi Perempuan dan Anak Korban Kekerasan untuk membentuk Pusat Pelayanan Terpadu Pemberdayaan Perempuan dan Anak (P2TP2A) (Utami, 2016).

Adapun dasar hukum mengenai pembentukan P2TP2A tersebut adalah
Peraturan Menteri Negara Pemberdayaan Perempuan dan Perlindungan Anak Nomor 5 Tahun 2010 tentang Panduan Pembentukan dan Pengembangan Pusat Pelayanan Terpadu. Peraturan tersebut mengatur bahwa masing-masing daerah kabupaten/kota mempunyai kewajiban membentuk Lembaga Pusat Pelayanan Terpadu Pemberdayaan dan Perlindungan Terhadap Perempuan dan Anak (Rosnawati, 2018). Pusat pelayanan terpadu tersebut berfungsi untuk memberikan layanan gratis bagi korban KDRT dalam segi medis, psikologis, hukum, dan perlindungan social (Ni'mah, 2012).

Pembentukan P2TP2A sebagai lembaga non-pemerintah tersebut merupakan respon pemerintah untuk memberikan layanan kepada perempuan dan anak korban kekerasan sehingga para korban tersebut dapat cepat terbantu dan tertangani dengan baik, mengingat bahwa kekerasan terhadap perempuan merupakan persoalan mendasar dalam kehidupan bermasyarakat dan berbangsa yang akan mempengaruhi kualitas hidup dan masa depan perempuan dan anak yang menjadi korban kekerasan, dan untuk itu harus ditangani secara komprehensif dan berkualitas dengan pendekatan yang berspektif korban (Komnas Perempuan dan Forum Pengada Layanan (FPL), 2017).

Namun, di dalam perkembangannya tidak semua P2TP2A dapat menjalankan perannya secara optimal. Seringkali P2TP2A memiliki permasalahan dalam hal koordinasi di antara aparat penegak hukum dan badan lainnya sehingga tidak dapat secara optimal melindungi hak-hak korban kekerasan (Herawati, Ani Purwanti, Sekar Anggun Gading Pinilih, 2019). Beberapa penelitian telah banyak dilakukan untuk mencari faktor penyebab ketidakoptimalan Pusat Pelayanan Terpadu di dalam menjalankan tugasnya. Sebagaimana penelitian yang dilakukan oleh Penny Naluria Utami dengan judul "Optimalisasi Pemenuhan Hak Korban Kekerasan Terhadap Perempuan Melalui Pusat Pelayanan Terpadu", didapatkan hasil bahwa ketidakoptimalan tersebut dapat dipengaruhi oleh masih minimnya dukungan 
dari pemerintah daerah terkait, seperti variasinya aturan daerah, pendanaan, sarana dan prasarana, dan sumber daya manusia. Belum semua daerah memiliki P2TP2A dikarenakan pula kurang respons dari pemerintah daerah terkait untuk memenuhi kebutuhan korban serta hak-haknya. Oleh karena itu, penelitian ini mencoba untuk melihat lebih dalam lagi dan melihat dari sisi yang lain dibandingkan penelitian-penelitian sebelumnya yang telah dilakukan.

Berdasarkan catatan Komnas Perempuan, hanya pemerintah Provinsi Jawa Timur, Jawa Tengah, Jawa Barat dan DKI Jakarta yang baru dapat memberikan dukungan memadai bagi pelaksanaan mandat P2TP2A, baik dari sisi anggaran maupun infrastrukturnya, sehingga P2TP2A di daerah tersebut dapat memberikan perannya dalam melakukan pendampingan korban (Komnas Perempuan dan Forum Pengada Layanan (FPL), 2017). Salah satu P2TP2A yang berada di Provinsi Jawa Tengah yaitu P2TP2A yang berada di Kabupaten Magelang. Menurut data dari Simfoni, bahwa Kabupaten Magelang merupakan salah satu kabupaten yang memiliki jumlah kasus kekerasan perempuan yang cukup tinggi. Tingginya jumlah kekerasan tersebut memberikan pertanyaan yang muncul apakah P2TP2A Kabupaten Magelang memiliki peran aktif dan responsif dalam mencari kasus kekerasan terhadap perempuan ataukah dari pihak masyarakatnya sendiri memang memiliki kesadaran yang tinggi untuk melaporkan, sehingga dari uraian tersebut, akan dicari jawaban mengenai faktor-faktor penyebab terjadinya KDRT, dan dianalisis apakah P2TP2A Kabupaten Magelang dalam memberikan layanan bagi perempuan dan anak korban KDRT terhadap perempuan sudah optimal atau belum dalam menjalankan fungsinya tersebut.

\section{B. Metode Penelitian}

Metode penelitian yang digunakan dalam penelitian ini adalah metode yuridis empiris. Penelitian yuridis empiris merupakan penelitian hukum mengenai pemberlakuan atau implementasi ketentuan hukum normatif secara in action pada setiap peristiwa hukum tertentu yang terjadi dalam masyarakat. Penelitian ini disebut dengan penelitian lapangan yaitu penelitian yang meneliti peraturan-peraturan hukum kemudian setelah itu dicocokkan dengan data dan perilaku yang hidup di tengahtengah masyarakat.

Pendekatan yang dilakukan dalam penelitian ini tidak hanya berpegang pada segi yuridisnya saja namun dengan bantuan ilmu sosial lainnya. Spesifikasi penelitian yang digunakan dalam penelitian ini adalah deskriptif analitis, sebab data yang diperoleh dari penelitian ini akan memberikan suatu penjelasan dengan memberikan suatu gambaran mengenai optimalisasi $\mathrm{P} 2 \mathrm{TP} 2 \mathrm{~A}$ dalam menangani asus KDRT di Kabupaten Magelang. Data yang digunakan adalah data primer melalui wawancara dan observasi, dan data sekunder melalui studi pustaka.

\section{Hasil dan Pembahasan}

\section{Faktor-faktor Penyebab Terjadinya Kekerasan Dalam Rumah Tangga}

KDRT sebagai kasus kekerasan yang terjadi di lingkup rumah tangga sebenarnya dapat terjadi kepada siapapun dalam lingkup rumah tangga, tidak hanya perempuan saja yang menjadi korbannya. Namun, dikarenakan belum tercapainya kesetaraan gender yang maksimal serta didukung dengan budaya patriarki yang masih melekat di masyarakat, maka KDRT seringkali terjadi kepada kaum wanita di lingkup rumah tangganya. Menurut Pasal 5 UU Nomor 23 Tahun 2004 tentang Penghapusan Kekerasan Dalam Rumah Tangga, KDRT tersebut dapat berwujud: (a) Kekerasan fisik; (b) Kekerasan psikis; (c) Kekerasan seksual; atau (d) Penelantaran rumah tangga.

Termasuk lingkup rumah tangga adalah: (Luhulima, 2000) a) Suami istri atau mantan suami istri; b) Orang tua dan anak-anak; c) Orang-orang yang mempunyai hubungan darah; d) Orang yang bekerja membantu kehidupan rumah tangga orang-orang yang menetap di sebuah rumah tangga; e) Orang 
yang hidup Bersama dengan korban atau mereka yang masih pernah tinggal Bersama (yang dimaksud dengan orang yang hidup Bersama adalah pasangan hidup Bersama atau beberapa orang tinggal Bersama dalam satu rumah untuk jangka waktu tertentu).

Faktor penyebab KDRT menurut hasil Survei Pengalaman Hidup Perempuan Nasional (SPHPN) tahun 2016 mengungkapkan terdapat 4 (empat) faktor penyebab terjadinya kekerasan fisik dan/atau seksual terhadap perempuan yang dilakukan di antaranya, yaitu: (Amanda \& Dian Puji Simatupang, 2019)

a. Faktor Individu Perempuan

Pernikahan yang dilakukan secara siri, kontrak, adat maupun lainnya memiliki potensi 1,42 kali lebih besar kekerasan fisik dan/atau seksual dibandingkan perempuan yang menikah secara resmi diakui negara melalui catatan sipil atau KUA, serta adanya faktor seringnya bertengkar dengan suami menyebabkan perempuan lebih berisiko 3,95 kali lebih tinggi mengalami kekerasan fisik dan/atau seksual.

b. Faktor Pasangan

Sebagian besar suami yang melakukan KDRT terhadap istrinya yaitu suami yang menganggur serta memiliki pasangan lain dan mempunyai kebiasaan seperti mabuk.

c. Faktor Ekonomi

Perempuan yang berasal dari rumah tangga dengan tingkat ekonomi yang semakin rendah cenderung memiliki resiko yang lebih tinggi untuk mengalami kekerasan fisik dan/atau seksual oleh pasangan.

d. Faktor Sosial Budaya

Perempuan yang memiliki rasa kekhawatiran akan bahaya kejahatan yang mengancam memiliki resiko 1,68 kali lebih besar mengalami kekerasan fisik dan/atau seksual oleh pasangan, daripada mereka yang tidak merasa khawatir.

Selain faktor-faktor di atas terdapat faktor lain penyebab terjadinya KDRT.
Salah satu faktor lain yang cukup mempengaruhi adalah tingkat pendidikan yang rendah. Terdapat penelitian yang dilakukan oleh ICRW bahwa wanita yang memiliki tingkat pendidikan rendah menikah pada usia muda. Survey penelitian yang dilakukan oleh ICRW pada negara berkembang seperti, Asia Tenggara, Afrika, serta Amerika latin menyatakan bahwa lebih dari $50 \%$ wanita yang menikah muda memiliki tingkat pendidikan yang rendah (03 tahun pendidikan), 40\% lainnya memiliki tingkat pendidikan menengah (4-7 tahun pendidikan) serta sisanya memiliki tingkat pendidikan tinggi ( $>8$ tahun pendidikan) (International Center For Research On Women, 2006). Hasil penelitian tersebut, menunjukkan adanya hubungan antara tingkat pendidikan rendah dengan usia muda. Wanita yang menikah di usia muda masih memiliki kematangan emosi yang rendah (Hurlock, 1997). Menurut Sanderwitz dan Paxman, pernikahan muda sering terjadi disebabkan seseorang berpikir secara emosional untuk melakukan pernikahan, mereka berpikir telah saling mencintai dan siap untuk menikah (Eka, Khairani, Rahma, Putri, 2008). Padahal, di dalam suatu kehidupan rumah tangga dibutuhkan suatu tingkat kematangan emosi yang sudah cukup tinggi supaya dapat mengendalikan hakikat perkawinan dan peran orang tua yang akan disandang (Adhim, 2002).

Wanita yang memiliki tingkat pendidikan yang rendah dapat dipengaruhi pula oleh faktor budaya jaman dahulu yang mengatakan bahwa seorang wanita pada hakekatnya akan kembali kepada dapur dan sumur. Hal ini berkaitan pula dengan ketidaksetaraan gender antara perempuan dan laki-laki, dimana perempuan hanya dianggap sebagai kaum marginal yang tidak pernah memiliki posisi yang setara dengan laki-laki. Pendidikan yang tinggi bukanlah suatu kewajiban yang harus dijalankan oleh mereka. Oleh karena itu, baik mereka sendiri maupun orang tua mereka akan berfikir bahwa keputusan menikah akan lebih memberikan manfaat dibandingkan harus 
menempuh tingkat pendidikan yang tinggi. Pendidikan yang rendah tersebut akan mempengaruhi kualitas rumah tangga seseorang wanita tersebut. Dengan menempuh pendidikan yang tinggi akan memberikan pola pemikiran wanita yang cukup matang dalam mengambil keputusan serta akan memberikan kualitas kehidupan rumah tangga yang lebih baik karena wanita dengan pendidikan tinggi akan mampu untuk membantu perekonomian di dalam rumah tangganya tersebut, sehingga wanita dengan pendidikan rendah yang menikah di usia muda tersebut cenderung rentan untuk terjadi perceraian di dalam rumah tangganya.

\section{Layanan bagi Perempuan dan Anak Korban KDRT oleh P2TP2A Kabupaten Magelang.}

P2TP2A hadir sebagai lembaga layanan yang melakukan pendampingan terhadap perempuan dan anak korban kekerasan yang berspektif gender, serta sebagai layanan untuk memberikan pemenuhan hak kepada perempuan korban kekerasan mengingat kasus kekerasan terhadap perempuan khususnya KDRT merupakan kasus yang tidak pernah mereda, kekerasan yang menimpa perempuan dapat menimbulkan berbagai macam persoalan psikologis, keadilan hukum dan pengabaian hak-hak kemanusiaan (Arbaiyah Prantiasih, Yuhdi dan Siti Awalliyah, 2015).

P2TP2A di Kabupaten Magelang atau yang disebut dengan P2TP2A Semanah merupakan bagian dari Dinas Sosial, Pengendalian Penduduk dan Keluarga Berencana, Pemberdayaan Perempuan dan Perlindungan Anak Kabupaten Magelang. Apabila mengacu kepada Peraturan Menteri Negara Pemberdayaan Perempuan dan Perlindungan Anak RI Nomor 01 Tahun 2010 tentang Standar Pelayanan Minimal (SPM) Bidang Layanan Terpadu bagi Perempuan dan Anak Korban Kekerasan tersebut pada Pasal 1 bahwa kinerja Unit Pelayanan Terpadu dalam pemenuhan hak bagi perempuan dan anak korban kekerasan meliputi 5 (lima) jenis layanan yakni: layanan pengaduan, layanan kesehatan, rehabilitasi sosial, penegakan dan bantuan hukum serta pemulangan dan reintegrasi sosial. Namun, kelima jenis layanan tersebut juga disesuaikan dengan ketersedaan keahlian, sumber daya manusia dan fasilitas yang ada (Utami, 2016).

Untuk P2TP2A Semanah sendiri terdapat bidang Perlindungan Perempuan dan Anak (PPA) untuk mengurusi perempuan dan anak korban kekerasan. Di dalam P2TP2A Semanah ini sendiri memiliki kasus kekerasan perempuan paling banyak adalah KDRT dari tahun ke tahun. Data kasus kekerasan berbasis gender P2TP2A Semanah pada tahun 2019 dapat dilihat pada Tabel 1. Adapun data kasus kekerasan berbasis gender P2TP2A Semanah pada tahun 2018 dapat dilihat pada Tabel 2.

Berdasarkan Standar Pelayanan Minimal (SPM) bidang Layanan Terpadu bagi Perempuan dan Anak Korban Kekerasan. Layanan pengaduan di dalam P2TP2A Semanah ini dapat dilakukan secara langsung maupun melewati media sosial. Pelapor yang melapor secara langsung biasanya diterima oleh pihak P2TP2A Semanah dengan cara mengisi form pengaduan secara tertulis dan ditanda tangani, pelaporan secara langsung tersebut tidak hanya korban saja yang dapat melapor tetapi laporan dapat dilakukan pula oleh orang lain seperti kerabat, keluarga maupun pendamping yang lainnya. Untuk pelaporan yang dilakukan melewati sosial media itu sendiri, setelah diterimanya informasi dari media maka hal pertama yang dilakukan oleh pihak P2TP2A Semanah adalah melakukan penggalian dan pengembangan informasi (crosscheck) terlebih dahulu untuk mendapatkan informasi yang sebenarnya. P2TP2A Semanah hanya memiliki 1 (satu) orang fulltimer. Namun, P2TP2A Semanah memiliki kader-kader pada setiap kecamatan atau desa yang berada di Kabupaten Magelang. Dimana, setiap kecamatan atau desa tersebut memiliki fasilitator yang bertugas untuk menampung laporan kekerasan yang terjadi dan nantinya akan 
berkoordinasi dengan pihak P2TP2A Semanah.

Selain layanan pengaduan kekerasan terhadap perempuan dan anak yang dimiliki oleh P2TP2A Semanah, sejak masa pandemi Covid-19 ini, terdapat strategi "jemput bola" yang disarankan oleh Kementerian Pemberdayaan Perempuan dan Perlindungan Anak (KEMENPPPA) dengan tujuan untuk meningkatkan penanganan KDRT. Strategi "jemput bola" tersebut merupakan dorongan kepada P2TP2A untuk lebih pro aktif dalam mencari dan menangani kasus KDRT di wilayah mereka masing-masing. Pandemi Covid-19 ini dapat meningkatkan jumlah KDRT, dikarenakan Covid-19 menyebabkan perekonomian semakin menurun sehingga berdampak dengan timbulnya KDRT yang dialami oleh perempuan.

Untuk layanan kesehatan bagi korban dilakukan oleh tenaga kesehatan dimana P2TP2A Semanah bermitra dengan Dinas Kesehatan Kabupaten Magelang, Rumah Sakit Jiwa serta RSUD Kabupaten Magelang. Mengingat, korban kekerasan ataupun KDRT dapat memberikan rasa trauma baik fisik, psikologis (mental) dan psikososial antara lain: (Dadang, 2009)

a. Fisik berupa luka fisik, kerusakan syaraf, pingsan, cacat permanen, gugur kandungan, kehamilan, gangguan organ reproduksi (infeksi), penyakit kelamin dan kematian.

b. Psikologis/mental berupa kehilangan nfsu makan, gangguan tidur (insomnia, mimpi buruk), cemas, takut, tidak percaya diri, hilang inisiatif/tidak berdaya, tidak percaya dengan apa yang terjadi, mudah curiga/paranoid, kehilangan akal sehat, depresi berat.

Seringkali perempuan korban KDRT mengalami depresi akibat kekerasan yang dilakukan oleh suaminya. Untuk ini, P2TP2A Semanah memiliki psikolog, dimana mekanismenya nanti korban akan didatangkan langsung ke rumah sakit. Hal ini dilakukan oleh P2TP2A Semanah dalam rangka pengobatan dan pemulihan kesehatan korban. Untuk rehabilitasi sosial, P2TP2A Semanah belum memiliki rumah aman.
Menurut Peraturan Pemerintah Nomor 4 Tahun 2006 tentang Penyelenggaraan dan Kerja Sama Pemulihan Korban Kekerasan Dalam Rumah Tangga bahwa penyelenggaraan pemulihan terhadap korban dilaksanakan oleh instansi pemerintah dan pemerintah daerah serta lembaga sosial dengan salah satu fasilitasnya adalah rumah aman.

Rumah aman diperlukan supaya perempuan korban kekerasan mendapatkan akses ke lingkungan yang bebas dari ketakutan dan memberikan kesempatan kepada perempuan korban kekerasan untuk menerobos siklus kekerasan (Kim \& Yang, 2016), memperbaiki kembali hubungan mereka dengan pasangannya, dan mempersiapkan transisi jangka panjang, bahkan rumah aman membuat perempuan yang dilecehkan dapat menghadapi perpisahan perkawinan dan masalah keuangan mereka setelah berpisah (Herawati, Sekar Anggun Gading Pinilih, 2020). Rumah aman tersebut akan digunakan sebagai tempat pelayanan serta pendampingan korban yang membutuhkan tempat aman dari gangguan-gangguan yang mengancamnya tersebut. Pendamping kekerasan dalam rumah tangga sering dihadapkan kesulitan pada saat mereka membantu korban untuk menemukan tempat yang aman (Sullivan \& Olsen, 2016). Dengan demikian dikarenakan belum memiliki rumah aman, maka apabila terdapat korban yang membutuhkan rumah aman biasanya akan dirujuk ke provinsi.

Untuk layanan bantuan dan penegakan hukum, P2TP2A Semanah melakukannya dengan 2 (dua) cara yaitu memberikan mediasi dengan cara memberikan advokasi kepada suami serta yang kedua yaitu melalui penegakan hukum. Untuk cara yang pertama yaitu memberikan advokasi kepada laki-laki atau suami korban, dengan cara advokasi mengenai UU Nomor 23 Tahun 2004 tentang Penghapusan Kekerasan Dalam Rumah Tangga bahwa perempuan atau istri tersebut bukanlah sebagai obyek kekerasan serta menegaskan pula bahwa sang istri memiliki kedudukan yang setara dengan 
suami. Hal menunjukkan bahwa kekerasan terhadap perempuan atau istri muncul sebagai salah satu bentuk manifestasi ketidaksetaraan gender (Nainggolan, 2017), sehingga menempatkan perempuan sebagai kaum yang lebih rendah serta mudah untuk dikuasai oleh laki-laki. Masyarakat Kabupaten Magelang juga memiliki keagamaan yang cukup kuat sehingga memandang bahwa suami merupakan seseorang yang harus dipatuhi. Oleh karena itu, kekerasan yang terjadi di dalam rumah tangga tersebut merupakan hal yang tabu untuk dilaporkan dan dianggap masalah pribadi dimana seharusnya orang luar tidak ikut campur masalah tersebut, serta akan merendahkan harkat dan martabat suami dan dianggap sebagai hal yang akan mempermalukan suami.

P2TP2A Semanah selain memberikan advokasi kepada suami, juga akan memenuhi keinginan perempuan korban KDRT dalam hal ingin memberikan efek jera bagi suaminya atau dalam hal ini melalui penegakan hukum. Apabila perempuan tersebut menghendaki untuk memberikan efek jera, maka pihak P2TP2A akan melakukan pendampingan untuk korban dari proses pengadilan sampai dengan pemulihan psikologi.

Untuk layanan terakhir, yaitu layanan pemulangan dan reintegrasi sosial, dimana layanan ini P2TP2A Semanah dapat bekerja sama dengan Dinas Sosial dalam rangka memberikan pelayanan pemulihan kepada korban. Pemerintah dalam hal ini memberikan support kepada perempuan korban KDRT dengan cara memberikan pelatihan keterampilan yang sifatnya sederhana dan dapat memberdayakan perempuan tersebut nantinya. Pelatihan keterampilan tersebut, juga dilakukan dalam upaya untuk diterima kembali di kalangan masyarakat ataupun keberadaannya dapat diterima dengan baik oleh masyarakat setempat. Dengan diterimanya kembali korban KDRT dengan baik serta adanya dukungan sosial yang didapat, maka hal tersebut akan berpengaruh terhadap perubahan kualitas hidup perempuan dan depresi yang dialami perempuan korban KDRT akan semakin berangsur membaik (Hitijahubessy, Yati Affiyanti \& Tri Budiati, 2018).

Berdasarkan pelayanan-pelayanan yang diberikan oleh P2TP2A Semanah tersebut, dapat diketahui upaya-upaya yang telah dilakukan oleh P2TP2A Semanah dapat dibedakan menjadi 3 (tiga) yaitu:

a. Upaya Pencegahan

Upaya pencegahan yang dilakukan P2TP2A Semanah yaitu diselenggarakannya kegiatan sosialisasi. Sosialisasi tersebut diselenggarakan di desa-desa, yang bertujuan untuk memberikan informasi serta meningkatkan kesadaran masyarakat bahwa kasus KDRT tersebut sudah bukan merupakan privasi dalam suatu rumah tangga dan para korban tersebut harus memiliki keberanian untuk melaporkannya demi mendapatkan hakhak mereka. Menurut P2TP2A Semanah sendiri untuk meningkatkan kesadaran masyarakat mengenai kekerasan terhadap perempuan tersebut membutuhkan proses dan waktu yang cukup lama ditambah dengan masyarakat yang agamis yang menganggap bahwa suami merupakan seseorang yang harus dipatuhi.

b. Upaya Penanganan

Upaya penanganan tersebut dilakukan apabila terjadi suatu kekerasan. Upaya penanganan yang dilakukan oleh P2TP2A Semanah ketika sudah terdapat laporan kekerasan yang masuk, kemudian P2TP2A Semanah melakukan assessment pada korban serta mencari tahu apa saja kebutuhan korban. Termasuk memberikan pelayanan medis, pelayanan psikologis, pelayanan hukum atau hanya sebatas konseling sesuai dengan kebutuhan korban (Rosnawati, 2018).

c. Upaya Pemulihan

Pemulihan korban KDRT tersebut dimaksudkan untuk memulihkan kondisi korban baik fisik maupun psikisnya, sehingga korban dapat 
menjalankan aktifitasnya sehari-hari dan dapat diterima di tengah masyarakat seperti semula dalam menjalankan kehidupannya (Rosnawati, 2018). Upaya pemulihan yang dilakukan oleh P2TP2A Semanah tersebut seperti memberikan pelatihan keterampilan kepada korban yang bertujuan untuk dapat memberdayakan korban. Pelatihan keterampilan tersebut seperti keterampilan menjahit maupun memasak yang nantinya diharapkan akan memberikan modal usaha agar keterampilan yang diberikan tidak siasia.

Tabel 1.

Data Kasus Kekerasan Berbasis Gender

Tahun 2019

\begin{tabular}{|c|c|c|c|c|}
\hline \multirow[t]{2}{*}{ Jenis Kasus } & \multicolumn{4}{|c|}{ Jumlah Kasus } \\
\hline & Triwulan I & Triwulan II & Triwulan III & Triwulan IV \\
\hline Kekerasan Fisik / KDRT & 4 & & 7 & 2 \\
\hline Kekerasan Psikis / KDRT & 5 & & 7 & 2 \\
\hline \multicolumn{5}{|l|}{ Kekerasan Seksual / KDRT } \\
\hline Penelantaran / KDRT & 1 & & 4 & \\
\hline \multicolumn{5}{|l|}{ Pelecehan Seksual } \\
\hline Perkosaan/Pemaksaan Hubungan & 1 & & & 1 \\
\hline Kekerasan Dalam Pacaran & & 1 & 1 & 2 \\
\hline Jaminan Perlindungan & & & & 1 \\
\hline Penganiayaan & & & 1 & 1 \\
\hline Perceraian & & & & 1 \\
\hline Perzinahan & 1 & & & \\
\hline Aborsi & & 1 & & \\
\hline \multicolumn{5}{|l|}{ Gono Gini } \\
\hline Persetubuhan & 1 & & & \\
\hline Hak Asuh Anak & 1 & & 1 & 2 \\
\hline Asusila (Pasal 281 KUHP) & 1 & 1 & 1 & \\
\hline ТРPО & & & & 1 \\
\hline HIV & & & 1 & \\
\hline Jumlah & 15 & 3 & 23 & 13 \\
\hline
\end{tabular}

Tabel 2.

Data Kasus Kekerasan Berbasis Gender Tahun 2018

\begin{tabular}{lcccc}
\hline \multicolumn{1}{c}{ Jenis Kasus } & \multicolumn{3}{c}{ Jumlah Kasus } \\
\cline { 2 - 5 } & Triwulan I & Triwulan II & Triwulan III & Triwulan IV \\
\hline Kekerasan Dalam Rumah Tangga & 17 & 11 & 4 & 6 \\
Penelantaran & 1 & & 1 & 2 \\
Pelecehan Seksual & & & & \\
Kekerasan Dalam Pacaran & 1 & 1 & 1
\end{tabular}




\begin{tabular}{|c|c|c|c|c|}
\hline \multirow[t]{2}{*}{ Jenis Kasus } & \multicolumn{4}{|c|}{ Jumlah Kasus } \\
\hline & Triwulan I & Triwulan II & Triwulan III & Triwulan IV \\
\hline Jaminan Perlindungan & & 2 & & \\
\hline Penganiayaan & & 2 & 3 & 1 \\
\hline Perceraian & 2 & & & \\
\hline Perzinahan & 1 & 1 & & \\
\hline Aborsi & & 1 & & \\
\hline \multicolumn{5}{|l|}{ Gono Gini } \\
\hline \multicolumn{5}{|l|}{ Persetubuhan } \\
\hline \multicolumn{5}{|l|}{ HIV } \\
\hline Jumlah & 22 & 18 & 9 & 9 \\
\hline
\end{tabular}

\section{Simpulan dan Saran}

P2TP2A Semanah memiliki kasus kekerasan terhadap perempuan dengan kasus yang paling mendominasi adalah KDRT setiap tahunnya. P2TP2A Semanah Kabupaten Magelang menangani KDRT melalui pelayanan-pelayanan serta pendampingan yang diberikannya. Pelayanan yang diberikan oleh P2TP2A Semanah tersebut antara lain layanan pengaduan, layanan kesehatan, layanan rehabilitasi sosial, layanan penegakan dan bantuan hukum, serta layanan pemulangan dan reintegrasi sosial. P2TP2A Semanah dalam menangani kasus KDRT tersebut sudah cukup komunikatif dan responsif ditunjukkan dengan banyaknya jejaring yang dimiliki P2TP2A Semanah di kecamatan dan desa di Kabupaten Magelang. Serta, mitramitra yang dimiliki oleh P2TP2A Semanah dalam hal menangani kasus KDRT pun sudah cukup baik. Namun, untuk fasilitas rumah aman sendiri belum dimiliki oleh P2TP2A Semanah dimana korban yang dirasa memerlukan rumah aman harus dirujuk ke provinsi terlebih dahulu.

Upaya yang dilakukan oleh P2TP2A Semanah untuk menangani kasus kekerasan terhadap perempuan yang cukup tinggi sudah cukup optimal ditunjukkan dengan pelayanan-pelayanan yang diberikannya. Namun, untuk mendukung kelengkapan fasilitas rumah aman bagi penanganan korban kekerasan tersebut ada baiknya pemerintah memberikan dukungan untuk membangun rumah aman untuk P2TP2A Semanah sehingga pelayanan yang diberikan untuk korban kekerasan semakin optimal.

P2TP2A Semanah sudah melakukan upaya untuk meningkatkan kesadaran masyarakat mengenai kasus kekerasan terhadap perempuan ataupun KDRT. Hal ini untuk menunjukkan bahwa kasus KDRT bukan merupakan ranah privasi lagi bagi rumah tangga seseorang serta seorang perempuan harus berani untuk memperjuangkan haknya. Hal ini dilakukan pula untuk mengoptimalkan kesetaraan gender bagi kaum laki-laki dan perempuan untuk menunjukkan bahwa posisi perempuan tersebut adalah setara dengan laki-laki. Masyarakat harus sadar bahwa perempuan bukan untuk menjadi obyek kekerasan serta perempuan harus memiliki pendidikan yang tinggi untuk melepaskan stigma masyarakat bahwa kaum perempuan adalah kaum marginal yang mudah untuk dikuasai oleh laki-laki.

\section{DAFTAR PUSTAKA}

Adhim, M. . (2002). Indahnya Pernikahan Dini. Jakarta: Gema Insani Press.

Amanda \& Dian Puji Simatupang, S. (2019). Perlindungan Hukum Terhadap Perempuan Korban KDRT di Tangerang Selatan. Indonesian Constitutional Law Jurnal Staatsrecht, 
3(1).

Arbaiyah Prantiasih, Yuhdi dan Siti Awalliyah, M. (2015). Model Perlindungan Hak Perempuan Korban Tindak Kekerasan Dalam Rumah Tangga. Jurnal Pendidikan Pancasila Dan Kewarganegaraan, 28(1), 16.

Dadang, H. (2009). Penyiksaan Fisik dan Mental Dalam Rumah Tangga. Jakarta: Balai Penerbit FKUI.

Eka, Khairani, Rahma, Putri, D. (2008). Kematangan Emosi Pada Pria Dan Wanita Yang Menikah Muda. Depok: Fakultas Psikologi Universitas Gunadarma.

Farid, M. R. A. (2019). Kekerasan Terhadap Perempuan dalam Ketimpangan Relasi Kuasa: Studi Kasus di Rifka Annisa Women's Crisis Center. SAWWA: Jurnal Studi Gender, 14(2), 180.

Fazraningtyas, Dini Rahmayani, Indana Fitriani Rahmah, Wi. A. (2020). Kejadian Kekerasan Pada Perempuan Selama Masa Pandemi Covid-19. Dinamika Kesehatan Jurnal Kebidanan Dan Keperawatan, 11(1), 363.

Herawati, Ani Purwanti, Sekar Anggun Gading Pinilih, R. (2019). The Implementation of Recovery Policy towards Women Victims of Marital Violence as to Mental Care in Central Java, Indonesia. 6th International Conference on Community Development (ICCD 2019), 436. Atlantis Press.

Herawati, Sekar Anggun Gading Pinilih, R. (2020). Prevention of Violence Against Women Through Improving the Quality of Life of Women in Indonesia. Proceedings of the International Conference on Community Development (ICCD 2020), 611. Atlantis Press.

Hitijahubessy, Yati Affiyanti \& Tri Budiati, C. N. M. (2018). Dukungan Sosial dan Kualitas Hidup Fisik Perempuan
Korban Kekerasan Dalam Rumah Tangga. JKT, 9(1), 27.

Hurlock, E. . (1997). Psikologi Perkembangan (5th ed.; I. dan Soedjarwo, Ed.). Jakarta: Erlangga.

Imam, Z., \& Bano, S. (2015). Patriarchy, Community Rights and Institutions for Education: Counter-discourse and Negotiation for Rights. Indian Journal of Gender Studies, 22(2), 282-299. https://doi.org/10.1177/0971521515574 608

International Center For Research On Women. Child Marriage and Education. , (2006).

Kim, G., \& Yang, S. (2016). An Ethnographic Study of a Shelter for Victims of Domestic Violence in Korea. Indian Journal of Gender Studies, 23(3), 376-392. https://doi.org/10.1177/0971521516656 076

Komnas Perempuan dan Forum Pengada Layanan (FPL). (2017). Keterpaduan Layanan yang Memberdayakan: Hasil Asesmen P2TP2A di 16 Provinsi. Retrieved from http://komnasperempuan.go.id/file/pdf_ file/2018/Publikasi/Keterpaduan Layanan Yang Memberdayakan. Hasil asesme

Luhulima, A. S. (2000). Pemahaman Bentuk-bentuk Tindak Kekerasan Terhadap Perempuan dan Alternatif Pemecahannya. Bandung: PT Alumni.

Mutmainah, Anisa, Santoso Tri Raharjo, Sahadi Humaedi, E. T. (2019). Upaya Penghapusan Kekerasan dalam Rumah Tangga Melalui Program Corporate Social Responsibility. Prosiding Penelitian \& Pengabdian Kepada Masyarakat, 260.

Nainggolan, T. (2017). Kekerasan terhadap Istri dalam Perspektif Gender. Sosio Konsepsia: Jurnal Penelitian Dan Pengembangan Kesejahteraan Sosial, 
14(3), 213.

Ni'mah, Z. (2012). Efektivitas Penegakan Hukum Penghapusan Kekerasan Dalam Rumah Tangga. Mimbar Hukum Fakultas Hukum Universitas Gadjah Mada, 24(1), 55-68. https://doi.org/10.22146/jmh.16141

Rosnawati, E. (2018). Peran Pusat Pelayanan Terpadu Pemberdayaan Perempuan dan Anak (P2TP2A) Dalam Mengatasi Kekerasan Dalam Rumah Tangga. Jurnal Kosmik Hukum, 18(1), 93.
Sullivan, C. M., \& Olsen, L. (2016). Common ground, complementary approaches: adapting the Housing First model for domestic violence survivors. Housing and Society, 43(3), 182-194. https://doi.org/10.1080/08882746.2017. 1323305

Utami, P. N. (2016). Optimalisasi Pemenuhan Hak Korban Kekerasan Terhadap Perempuan Melalui Pusat Pelayanan Terpadu. Jurnal Hak Asasi Manusia, 7(1), 60. 